\title{
PROFIL TAKSONOMI PENGETAHUAN SISWA SMP DALAMPEMECAHAN MASALAH SOAL CERITA SISTEM PERSAMAAN LINEAR DUA VARIABEL DITINJAU DARI GAYA KOGNITIF
}

\author{
Rahmawati Patta ${ }^{1}$, Syafruddin Syafar ${ }^{2}$, Bahar $^{3}$ \\ ${ }^{1}$ PGSD FIP UNM \\ rahmawati@unm.ac.id \\ ${ }^{2}$ SMPN 5 Marioriwawo Soppeng \\ ${ }^{3}$ FKIP Universitas Sawerigading \\ baharmat@yahoo.co.id
}

\begin{abstract}
The Study aimed at discovering (1) the profile of knowledge taxonomy of student in solving story problem of linear equation system of two variables based on cognitive style, (2) the comparison of knowledge taxonomy of student in solving story problem of linear equation system of two variables based on cognitive style.The Study is a qualitative research. The instrument of the study was the researcher himself as the main instrument guided by tasks in solving story problem of linear equation system of two variables and a valid, reliable guided interview. Data were collected by conducting task based interview. The subjects of the study were two grade VIII students of SMPN 5 Marioriwawo in Soppeng district consisted of one student who categorized as field independent named as SFI (subject field independent) and one student who categorized as field dependent named as SFD (subject field dependent).
\end{abstract}

Keyword: knowledge taxonomy, cognitive style, SPLDV, metacognitive

\section{PENDAHULUAN}

kategori yaitu pengetahuan faktual, pengetahuan konseptual, pengetahuan prosedural, dan pengetahuan metakognitif.

Hasil survei menunjukkan bahwa pada umumnya siswa mengalami kesulitan dalam menjawab soal-soal yang berbentuk soal cerita, pengalaman peneliti sendiri sebagai guru dan terkhusus pada sekolah SMP Negeri 5 Marioriwawo ketika siswa diberi soal cerita cenderung siswa mengalami kesulitan dan bahkan hampir semua siswa salah dalam memecahkan masalah soal cerita yang diberikan, hal ini ditunjukkan pada data-data sebagai berikut:

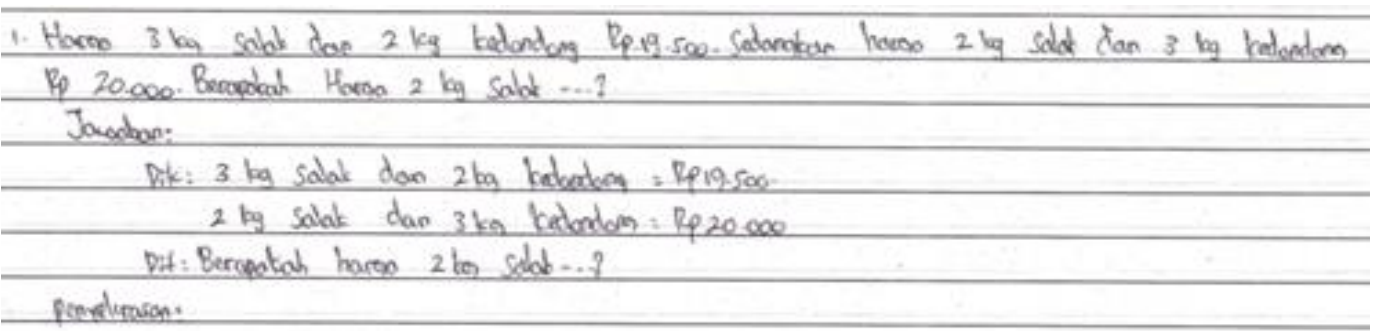




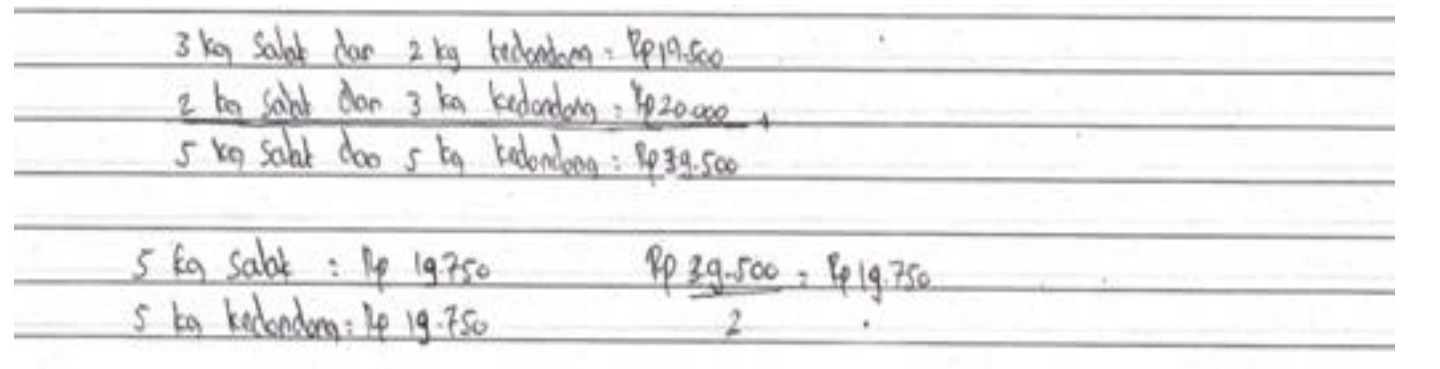

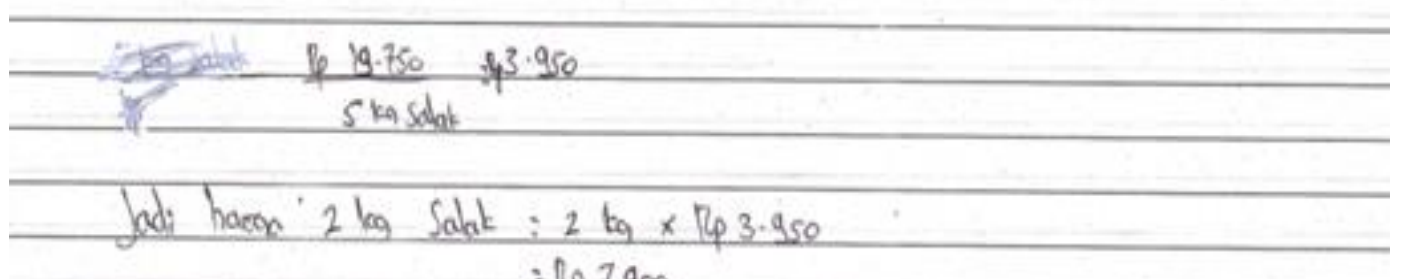

\section{$=167.800$}

Berdasarkan penyelesaian soal cerita tersebut terlihat bahwa siswa mampu mengetahui fakta atau istilah yang dinyatakan secara eksplisit dalam pemecahan masalah soal cerita sistem persamaan linear dua variabel dalam menuliskan apa yang diketahui dan yang ditanyakan dalam bentuk verbal, siswa tidak mampu menuliskan model matematika. Siswa tidak mampu melakukan proses operasi dengan tepat terhadap metode eliminasi, substitusi, siswa tidak mampu menentukan titik potong untuk setiap persamaan garis, dan tidak menunjukkan gambar grafik dalam

\section{Jenis Penelitian}

Jenis penelitian ini dikategorikan ke dalam penelitian kualitatif dengan pendekatan deskriptif-eksploratif.

\section{Lokasi dan Subjek Penelitian}

Penelitian dilaksanakan di SMP

Negeri 5 Marioriwawo Kabupaten

Soppeng dengan memilih 2 siswa kelas VIII sebagai subjek penelitian, yang terdiri dari 1siswa subjek Field-dependent (FD) dan 1 siswa subjek Field-independent (FI)

Adapun langkah-langkah pemilihan subjek penelitian adalah sebagai berikut: pemecahan masalah soal cerita sistem persamaan linear dua variabel.Oleh karena itu dari permasalahan yang ada peneliti tertarik untuk mengetahui taksonomi pengetahuan siswa dalam pemecahan masalah soal cerita khususnya pada materi sistem persamaan linear dua variabel ditinjau dari gaya kognitif siswa.

Berdasarkan latar belakang yang telah diuraikan, maka dalam penelitian ini yang akan diteliti adalah dengan judul: "Taksonomi pengetahuan siswa dalam pemecahan masalah soal cerita sistem persamaan linear dua variable ditinjau dari gaya kognitif".

\section{METODE PENELITIAN}

1. Menetapkan kelas yaitu kelas VIII SMP tahun pelajaran 2012/2013 dengan pertimbangan bahwa siswa kelas VIII sudah mendapat materi ajar sitem persamaan linier dua variabel pada semester ganjil.

2. Pemberian tes GEFT kepada kelas yang telah ditetapkan

3. Menganalisis hasil tes GEFT yang telah diberikan kepada siswa

4. Mengelompokkan siswa ditinjau dari hasil tes GEFT. Siswa yang berada 
pada field independent dan fielddependent

5. Memilih minimal satu subjek untuk tiap kelompok dengan mempertimbangkan nilai ekstrim artinya siswa yang memperoleh skor tes GEFT .

6. Jika masing-masing kelompok terdapat minimal satu subjek yang memenuhi kreteria poin 5 maka calon subjek akan dijadikan subjek penelitian

7. Jika tidak ditemukan minimal satu subjek pada tiap-tiap kelompok maka akan dilakukan langkah 1, 2, 3, 4, 5, dan 6.

\section{Instrumen Penelitian}

Instrumen penelitian ini adalah peneliti sendiri yang berpandu pada pedoman wawancara dan tes diagnostik.

\section{Prosedur Penelitian}

1) Tahap Persiapan, dan 2) Tahap Pelaksanaan

\section{Teknik Pengumpulan Data}

Pengumpulan data dalam penelitian ini terdiri dari: 1) data dari hasil tes diagnostik, 2) wawancara berbasis tugas.

Langkah-langkahpengumpulandan validasidatadalampenelitian ini adalah:

1. Dilakukan pengambilan data denga carasubjekdiberikan Tes diagnostik (TD) . Untuk mendapatkan data sesuai yang diteliti dilakukan wawancara

\section{HASIL PENELITIAN DAN PEMBAHASAN}

Subjek penelitian dipilih dengan langkah-langkah, pemberian tes GEFT, selanjutnya diklarifikasi untuk melihat siswa yang berada pada kategori Field Independent (FI) dan Field Dependent (FD) yang akan dijadikan sebagai subjek penelitian.Kemudian dari kedua subjek yang dipilih akan diberikan tes diagnostik (terdiri dari dua jenis soal) untuk melihat profil taksonomi pengetahuan kedua subjek tersebut. Selanjutnya dari hasil jawaban tes diagnostik kedua subjek tersebut diperiksa lalu diadakan berbasis tugas dan direkam. Hasil rekaman wawancara dibuatkan transkrip yangdilengkapidengankode.Data dari TD berupa: transkrip wawancara, hasil tugas, dan catatanlapangan dimasukkandalambundel yang berbeda (bundel I:data wawancara I, bundelII: data wawancara II)

2. Dilakukantriangulasidengancara:data wawancara I dandata wawancara II dibandingkan.Jikahasildaritriangulasii ni, menunjukkan bahwadata Wawancara

Ikonsisten,makadiperolehdatayang valid,dan data dijadikan acuan dalam menganalisis data untuk menjawab pertanyaan penelitian

3. Jikahasiltriangulasiyang dilakukanmenunjukkanbahwadata wawancaratidakkonsisten,makadilaku kanpengambilandata tahapke-i dengancara subjekdiberi wawancara ke-i,i $\geq 3$.Data ke-idibandingkan dengandatake $\quad \mathrm{i}-\mathrm{j}, \quad \mathrm{j}=1,2, . \mathrm{i}-$ 1.Halinidilakukanberulangkali sampai diperoleh datavalid.

\section{Teknik Analisis Data}

Analisis data dilakukan dengan langkah-langkah sebagai berikut: 1) Reduksi data, 2) Penyajian data, dan 3) Menarik kesimpulan

wawancara untuk menelusuri secara mendalam profil taksonomi pengetahuan siswa. Dari hasil penelitian diperoleh:

a. Taksonomi pengetahuan subjek field independent dalam pemecahan SPLDV berdasarkan jenis soal.

1. Pengetahuan faktual Subjek field independent (SFI) mengenal dan menggunakan simbol-simbol matematika dalam soal cerita, kemudian Subjek field independent (SFI) menuliskan apa yang diketahui dan ditanyakan dalam soal cerita, yaitu subjek field 
independent (SFI) menunjukkan apa yang diketahui dan yang ditanyakan. Berdasarkan analisis data tersebut diatas maka disimpulkan bahwa pengetahuan faktual dalam pemecahan masalah soal cerita sistem persamaan linear dua variabel subjek field independent (SFI) mengetahui fakta atau istilah yang dinyatakan secara eksplisit

2. Pengetahuan Konseptual

Subjek field independent (SFI) menggambarkan atau membuat model matematika dari soal cerita yaitu, subjek field independent (SFI) menuliskan soal cerita kedalam suatu persamaan, dan memilih dan menetapkan cara yang dapat digunakan dalam menyelesaikan soal cerita, yaitu subjek field independent (SFI) memahami konsep dalam membuat model matematika dan menetapkan metode atau cara dalam pemecahan masalah soal cerita sistem persamaan linear dua variabel. Berdasarkan analisis data tersebut diatas maka disimpulkan bahwa subjek field independent (SFI) menuliskan model matematika dan dan persamaan garis lurus serta menetapkan suatu metode dalam pemecahan masalah soal cerita sistem persamaan linear dua variabel.

3. Pengetahuan procedural subjek field independent (SFI) mampu melakukan proses operasi dengan tepat terhadap metode eliminasi, substitusi dan grafik serta mampu melakukan proses operasi dengan tepat untuk menentukan persamaan garis kedua semut yang berpotongan pada titik $(3,2)$

4. Pengetahuan metakognitif
Pengetahuan metakognitif (PM) menunjukkanbahwa, pengetahuan tentang diri sendiri subjek field independent (SFI) menunjukkan bahwa, subjek field independent (SFI) menyadari akan kelebihan dan kekurangan serta kesulitan dan kesalahan yang dilakukan dalam pemecahan masalah soal cerita sistem persamaan linear dua variabel, yaitu: (1) Subjek field independent (SFI) mengalami kesulitan dalam menentukan hasil dalam pemecahan masalah soal cerita sistem persamaan linear dua variabel, (2) Subjek field independent (SFI) sadar akan kelebihan dan kekurangan dalam pemecahan masalah soal cerita sistem persamaan linear dua variabel, (3) Subjek field independent (SFI) sadar akan kesalahan yang dilakukan dalam pemecahan masalah soal cerita sistem persamaan linear dua variabel, yaitu Subjek field independent (SFI) mampu menyadari akan kekurangannya setelah dilakukan penelusuran wawancara berbasis tugas, subjek menyatakan dengan menggunakan metode substitusi diperoleh $9000=9000$ namun yang sebenarnya adalah $0=$ 6000 , hal ini subjek menyadari setelah menggunakan metode substitusi dalam pemecahan masalah soal cerita sistem persamaan linear dua variabel, kemudian pada soal nomor 2 Subjek field independent (SFI) menyatakan dengan menggunakan metode substitusi dan eliminasi subjek menyatakan karena pindah keruas kanan maka berubah tandanya, kemudian subjek akan sadar dengan taksonomi pengetahuan yang dilakukan, subjek 
menuliskan lintasan yang dilalui membentuk garis lurus jika kedua semut melalui titik $(0,0)$ dan $(3,2)$, namun setelah ditelusuri, subjek sadar dan menyatakan bahwa semut pertama melalui titik $(0,0)$ dan titik $(3,2)$ semut yang kedua melalui titik $(0,-2)$ dan titik $(3,2)$. dalam pemecahan masalah soal cerita sistem persamaan linear dua variabel. Berdasarkan analisis data tersebut diatas maka disimpulkan bahwa subjek field independent (SFI) sadar akan kelebihan dan kekurangan dalam pemecahan soal cerita sistem persamaan linear dua variabel.

b. Taksonomi pengetahuan subjek field dependent (SFD) dalam pemecehan soal cerita SPLDV berdasarkan jenis soal

1. Pengetahuan Konseptual

Untuk soal nomor satu Subjek field dependent (SFD) menggambarkan atau membuat model matematika dari soal ceritasedangkan pada soal nomor 2 yaitu, subjek field dependent (SFD) tidak dapat membuat model matematika atau persamaan garis lurus dari soal cerita sistem persamaan linear dua variabel, yaitu subjek field dependent (SFD) memahami konsep dalam membuat model matematika yaitu $x+3 y=9000 \quad$ dan $2 x+6 y=12000$ pada soal nomor 1 . sedangkan pada soal nomor 2 subjek field dependent (SFD) tidak menuliskan beberapa model matematika atau persamaan garis lurus soal cerita sistem persamaan linear dua variable seperti diantaranya yang dituliskan pada lembar jawaban subjek.

2. Pengetahuan Prosedural subjek field dependent (SFD) memilih dan menetapkan cara yang dapat digunakan dalam menyelesaikan soal cerita, yaitu subjek field dependent (SFD) menetapkan metode atau cara dalam pemecahan masalah soal cerita sistem persamaan linear dua variabel pada soal nomor 1 yaitu metode grafik. kemudian pada soal nomor 2 subjek field dependent (SFD) menentukan langkah-langkah untuk menentukan titik potong dengan menggunakan substitusi dalam pemecahan masalah soal cerita sistem persamaan linear dua variabel

3. Pengetahuan metakognitif

Berdasarkan pengetahuan metakognitif (PM) menunjukkanbahwa, pengetahuan tentang diri sendiri subjek field dependent (SFD) menunjukkan bahwa, subjek field dependent (SFD) menyadari akan kelebihan dan kekurangan serta kesulitan dan kesalahan yang dilakukan dalam pemecahan masalah soal cerita sistem persamaan linear dua variabel, yaitu: (1) Subjek field dependent (SFD) mengalami kesulitan dalam menentukan hasil dalam pemecahan masalah soal cerita sistem persamaan linear dua variabel, (2) Subjek field dependent (SFD) sadar akan kelebihan dan kekurangan dalam pemecahan masalah soal cerita sistem persamaan linear dua variabel, (3) Subjek field dependent (SFD) sadar akan kesalahan yang dilakukan dalam pemecahan masalah soal cerita sistem persamaan linear dua variabel, yaitu pada soal nomor 1 Subjek field dependent (SFD) mengalami kesulitan hanya terdiam dan tidak bisa menjawab 
pada saat ditanya yang terkait dengan hasil pekerjaan subjek sendiri yang ada pada lembar jawaban subjek. Kemudian subjek field dependent (SFD) sadar akan pengetahuan yang dilakukan, setelah subjek ditanya mengapa kamu menuliskan $\mathrm{x}$ dan y pada model matematika yaitu subjek menyatakan bahwa $\mathrm{x}$ dan $\mathrm{y}$ yaitu garis yang berpotongan pada titik $\mathrm{x}$ dan $\mathrm{y}$. Selanjutnya pada soal nomor 2 Subjek field dependent (SFD) menyatakan bahwa untuk menentukan suatu persamaan langsung saja menuliskan persamaan garis setelah membaca soal kemudian menentukan titik potong, namun yang sebenarnya adalah persamaan garis lurus didapat dengan menggunakan metode grafik atau dengan menggunakan rumus persamaan garis lurus.

c. Perbedaan taksonomi pengetahuan SFI dan SFD dalam pemecahan masalah soal cerita.

1. Pengetahuan Konseptual

Subjek field independent (SFI) menggambarkan atau membuat model matematika dari soal cerita dan subjek field independent (SFI) mampu membuat model matematika atau persamaan garis lurus dari soal cerita sistem persamaan linear dua variabelsedangkan subjek field dependent (SFD) menggambarkan atau membuat model matematika dari soal cerita, tetapi pada soal nomor 2 subjek field dependent (SFD) tidak membuat model matematika atau persamaan garis lurus dari soal cerita sistem persamaan linear dua variabel. Kemudain subjek field independent (SFI) menuliskan soal cerita kedalam suatu persamaan dan menuliskan beberapa persamaan garis lurus soal cerita sistem persamaan linear dua variable seperti diantaranya yang dituliskan pada lembar jawaban subjek pada soal nomor 2. Sedangkan subjek field dependent (SFD) menuliskan soal cerita kedalam suatu persamaan namun subjek field dependent (SFD) tidak menuliskan beberapa model matematika atau persamaan garis lurus soal cerita sistem persamaan linear dua variable

2. Pengetahuan procedural Subjek field independent (SFI) dan subjek field dependent (SFD) melakukan operasi penjumlahan dan pengurangan terhadap proses eliminasi dan substitusi sedangkan Subjek field independent (SFI) melakukan dengan tepat proses metode grafikpada soal nomor 1 dan 2,yaitu subjek field independent (SFI) mengetahui prosedur yang digunakan dalam menyelesaikan persamaan dengan menggunakan metode eliminasi dan substitusi, sedangkan subjek field dependent (SFD) mengoprasikan dari setiap prosedur yang dia gunakan namun tidak mampu mengetahui bahwa hasil yang dia peroleh adalah tidak sesuai dengan jawaban yang sebenarnya, namun pada prosedur penyelesaian dengan metode substitusi subjek field independent (SFI) mengetahui prosedur operasi aljabar. kemudian pada soal nomor 2 subjek field independent (SFI) mengetahui prosedur yang digunakan dalam menentukan garis lurus pada bidang grafik XOY, salah satu yang diperoleh subjek adalah dimulai dari titik $(0,0)$ dan berpotongan pada titik 
$(3,2)$. Sedangkan subjek field dependent (SFD) menentukan titik potong dari setiap persamaan terlebih dahulu, kemudian menggambarkan grafiknya sehingga subjek field dependent (SFD) mendapatkan garis yang sejajar dan tidak mempunyai himpunan penyelesaian. Selanjtnya subjek field independent (SFI) dan subjek field dependent (SFD) melakukan dengan tepat proses metode grafik, yaitu subjek field independent (SFI) menentukan titik potong dari setiap persamaan terlebih dahulu, kemudian menggambarkan grafiknya sehingga subjek field independent (SFI) mendapatkan garis yang sejajar dan tidak mempunyai himpunan penyelesaian. sedangkan pada soal nomor 2 yaitu subjek field dependent (SFD) tidak mengetahui prosedur yang digunakan dalam menentukan garis lurus pada bidang grafik XOY, salah satu yang dilakukan subjek adalah subjek menuliskan $x+2 y=3$ pada persamaan pertama dan $x+y=3,2$ pada persamaan kedua hal ini tidak sesuai dengan gambar grafik yang dibuat oleh subjek field dependent (SFD). Subjek field dependent (SFD) tidak melakukan operasi untuk menentukan persamaan garis lurus, yaitu subjek field dependent (SFD) menyatakan bahwa titik $(3,2)$ garis lurus $\mathrm{x}$ dan garis lurus y dan subjek tidak mampu melakukan operasi perkalian, pembagian pada saat menentukan titik potong seperti yang ditunjukkan pada lembar jawaban subjek menyatakan bahwa $0+2 y=3 \rightarrow 2 y=\frac{3}{2}$.

Dan titk potong yang diperoleh adalah $(1,5)$

3. Pengethauan Metakognitif

Pengetahuan strategis pada subjek field independent (SFI) memikirkan startegi dan konsep yang akan digunakan dalam pemecahan masalah soal cerita sistem persamaan linear dua variabel, yaitu: (1) Subjek field independent (SFI) memikirkan apa yang dimisalkan dengan $x$ dan $y$ dalam menuliskan model matematika soal cerita sistem persamaan linear dua variabel pada soal nomor 1 dan soal nomor 2, sedangkan Subjek field dependent (SFD) tidak memikirkan strategi dalam mengambarkan grafik persamaan garis lurus pada soal nomor 2 , (2) Subjek field independent (SFI) memikirkan metode yang digunakan dalam menentukan nilai $x$ dan $y$ dalam soal cerita sistem persamaan linear dua variable pada soal nomor 1 , sedangkan pada soal nomor 2 Subjek field independent (SFI) dan subjek field dependent (SFD) memikirkan metode yang digunakan dalam menentukan nilai $x$ dan $y$ serta menentukan persamaan garis lurus, yaitu subjek menggunakan variable $\mathrm{x}$ dan variabel y dalam pemisalan untuk membuat model matematika, subjek field independent (SFI) memikirkan strategi untuk mengambarkan garis lurus yang bisa berpotongan pada titik $(3,2)$ pada bidang XOY yang dimulai dari titik apa saja yang mungkin terjadi. Kemudian subjek field independent hanya dapat menggunakan rumus 
$y=a x+b$ untuk menentukan suatu persamaan garis dalam pemecahan masalah soal cerita system persamaan linear dua variable sedangkan subjek field dependent (SFD) tidak memikirkan strategi dalam menentukan grafik karena subjek field dependent (SFD) menuliskan bahwa $\mathrm{y}=0$ maka $\mathrm{x}$ $=3$ dan dan digrafik terlihat berpotongan pada titik $(3,0)$. Kemudian subjek field dependent menggunakan metode grafik dalam menentukan persamaan persamaan garis dalam pemecahan masalah soal cerita system persamaan linear dua variable

Persamaan taksonomi SFI dan SFD terletak pada pengetahuan factual dimana subjek field independent (SFI) dan subjek field dependent (SFD) mengenal dan menggunakan simbol-simbol matematika dalam soal cerita nomor 1 dan soal nomor 2, kemudian Subjek field independent (SFI) dan subjek field dependent (SFD) menuliskan apa yang diketahui dan ditanyakan dalam soal cerita nomor 1 dan nomor 2 .

Pengetahuan tentang Tugas Kognitif pada subjek field independent (SFI) menunjukkan bahwa, subjek field independent (SFI) memilih strategi yang tepat dan konsep yang akan digunakan dalam pemecahan masalah soal cerita sistem persamaan linear dua variabel, yaitu: (1) Subjek field independent (SFI) dan subjek field dependent (SFD) memilih metode eliminasi dan substitusi serta metode grafik dalam pemecahan masalah soal cerita sistem persamaan linear dua variabel pada soal nomor 1, (2) Subjek field independent (SFI) mengetahui konsep dalam menggunakan metode eliminasi dan substitusi serta metode grafik dalam pemecahan masalah soal

\section{KESIMPULAN DAN SARAN}

cerita sistem persamaan linear dua variabel, sedangkan subjek field dependent (SFD) tidak memilih metode dengan tepat untuk menentukan persamaan garis lurus dalam pemecahan masalah soal cerita sistem persamaan linear dua variabel, dan subjek field dependent (SFD) tidak menegetahui konsep dalam menentukan persamaan garis lurus dalam pemecahan masalah soal cerita sistem persamaan linear dua variabel, yaitu Subjek field independent (SFI) menggunakan metode eliminasi dan metode substitusi dalam pemecahan masalah soal cerita sistem persamaan dua variabel, dengan menggunakan metode eliminasi subjek menyatakan bahwa nilai yang diperoleh adalah $0=6000$, juga dengan menggunakan metode substitusi subjek memperoleh $0=6000$.

Sedangkan subjek field dependent (SFD) memikirkan strategi untuk mengambarkan garis lurus yang bisa berpotongan pada titik $(3,2)$ pada bidang XOY yang dimulai dari titik apa saja yang mungkin terjadi, namun setelah ditelusiri ternyata subjek field dependent (SFD) tidak memikirkan strategi dalam menentukan grafik karenan subjek field dependent (SFD) menuliskan bahwa $\mathrm{y}=0$ maka $\mathrm{x}=3$ dan digrafiknya terlihat berpotongan pada titik $(3,0)$. Kemudian subjek field dependent menggunakan metode grafik dalam menentukan persamaan garis, sedangkan pada soal nomor 2 subjek field dependent (SFD) tidak menggunakan rumus dalam menentukan persamaan garis lurus, dalam pemecahan soal cerita sistem persamaan linier dua variable, selanjutnya Subjek field dependent (SFD) tidak mengetahui konsep dalam menetukan persamaan garis lurus subjek hanya menentukan titik potong kemudian menggambar grafik jadi tekesan bahwa persamaan sudah ditentukan padahal persamaan garis luruslah yang akan ditentukan nantinya.

\section{A. Kesimpulan \\ Persamaan Subjek Field Independent (SFI) dan Subjek}


Field Dependent (SFD) Tentang Taksonomi pengetahuan dalam Pemecahan Soal Cerita SPLDV

1). Pengetahuan Faktual (PF) Pada pengetahuan faktual ini, subjek field independent (SFI) dan subjek field dependent (SFD) mengetahui fakta atau istilah yang dinyatakan secara eksplisit dalam pemecahan masalah soal cerita sistem persamaan linear dua variabel.

2). Pengetahuan Konseptual (PK) Pada pengetahuan konseptual ini, subjek field independent (SFI) dan subjek field dependent (SFD) menuliskan model matematika dan menetapkan suatu metode serta mampu menuliskan persamaan garis lurus dalam pemecahan masalah soal cerita sistem persamaan linear dua variabel.

3). Pengetahuan Metakognitif (PM) Pada pengetahuan metakognitif ini, subjek field independent (SFI) dan subjek field dependent (SFD) sadar akan kelebihan dan kekurangan serta kesalahan dalam pemecahan soal cerita sistem persamaan linear dua variabel.

Perbedaan Subjek Field Independent (SFI) dan Subjek Field Dependent (SFD) Tentang Taksonomi pengetahuan dalam Pemecahan Soal Cerita PLDV

1). Pengetahuan Konseptual (PK) Pada pengetahuan konseptual ini, subjek field independent (SFI) dan subjek field dependent (SFD) menuliskan model matematika dan menetapkan suatu metode dalam pemecahan masalah soal cerita sistem persamaan linear dua variabel. Sedangkan subjek field dependent (SFD) tidak menuliskan beberapa model matematika atau persamaan garis lurus pada soal nomor 2

2). Pengetahuan Prosedural (PP)

Pada pengetahuan prosedural ini, subjek field independent (SFI) melakukan proses operasi dengan tepat terhadap metode eliminasi dan substitusi serta grafik serta mampu menentukan persamaan garis kedua semut yang berpotongan pada titik $(3,2)$ sedangkan subjek field dependent (SFD) tidak melakukan proses operasi dengan tepat untuk menentukan persamaan garis kedua semut yang berpotongan pada titik $(3,2)$.

3). Pengetahuan Metakognitif (PM) Pada pengetahuan metakognitif ini, subjek field independent (SFI) dan subjek field dependent (SFD) memilih strategi dengan tepat yang akan digunakan dalam pemecahan soal cerita sistem persamaan linear dua variabel pada soal nomor 1 . Sedangkan pada soal nomor 2 subjek field dependent (SFD) tidak mampu memikirkan dan memilih strategi yang tepat yang akan digunakan untuk menentukan persamaan garis lurus dalam pemecahan masalah soal cerita sistem persamaan linear dua variabel pada soal nomor 2 .

\section{B. Saran}

Mengacu kepada deskripsi pembahasan hasil penelitian dan kesimpulan di atas maka berikut akan dikemukakan beberapa saran antara lain: Bagi guru-guru terutama guru matematika diharapkan memberikan pengajaran yang membuat siswa tidak hanya menghapal konsep, melainkan memahami konsep sehingga mampu mengoprasikan operasi aljabar secara tepat dalam pemecahan masalah soal cerita sistem persamaan linear dua variabel. Kemudian Penelitian 
ini hanya terfokus pada upaya mendeskripsikan taksonomi pengetahuan siswa, sehingga disarankan kepada para

\section{DAFTAR RUJUKAN}

Alimuddin. 2012 Proses BerpikirKreatif MahasiswaCalon GuruKreatif dalam Pemecahan Masalah MatematikaBerdasarkan Gender . Disertasi Tidak diterbitkan Surabaya: PPs. UniversitasNegeri Surabaya.

Anderson, Lorin W (2010). Kerangka Landasan Untuk Pembelajaran, pengajaran,dan Assesmen. Yokyakarta: Pustaka Pelajar.

Aunurrahman. 2011. Belajar dan Pembelajaran. Bandung: Alfabeta.

Departemen Pendidikan Nasional. 2003. Kamus Besar Bahasa Indonesia. Jakarta: Balai Pustaka.

2006. Standar Isi Untuk Satuan Pendidikan Dasardan Menengah. Jakarta: Kegiatan Pengembangan Sistem dan Pengendalian Program SMP.

Gie , Liang. 1999. Filsafat Matematika. Yogyakarta: Pusat Belajar Ilmu Berguna.

Nasution. 2009. Berbagai Pendekatan dalam Proses Belajar \& Mengajar. Jakarta: PT Bumi Aksara.

Nurdin. 2006. Model Pembelajaran Matematika Untuk Menumbuhkan Kemampuan Metakognitif . Disertasi. Tidak Diterbitkan. Surabaya: PPs. Universitas Negeri Surabaya. peneliti selanjutnya untuk melakukan penelitian lebih lanjut guna memperluas hasil-hasil penelitian ini.

Pasenrengi. 2012. Profil Kesalahan Siswa dalam Menyelesaikan Masalah Limit Fungsi Aljabar Pada Siswa SMA Negeri 19 Makassar Tahun Pelajaran 2011/2012.. Tesis. Tidak Diterbitkan. Makassar: PPs UNM.

Pramita, Dewi. 2011. Analisis Kesalahan Menyelesaikan Soal Cerita Sistem Persamaan Linear Dua Variabel (SPLDV) Pada Siswa Kelas VIII SMP Negeril8 Makassar. Tesis. Tidak Diterbitkan. Makassar: PPs UNM

Sardiman. 2011. Interaksi dan Motivasi Belajar Mengajar. Jakarta: PT Raja Grafindo Persada.

Setiarso, Bambang. 2006. Manajemen Pengetahuan (Knowledge Management) danProses Penciptaan Pengetahuan. (IlmuKomputer.com, Diakses Tanggal 21 Januari 2013)

Slameto. 2010 Belajar dan Faktor-Faktor yang Mempengaruhinya. Jakarta: PT Rineka Cipta

Slavin. 2008. Psikologi Pendidikan Teori dan Praktek. Jakarta: PT Indeks

Suherman, Erman. 2003. Strategi Pembelajaran Matematika Kontemporer. Bandung: Universitas Pendidikan Indonesia

Suryasubrata, Sumadi. 2004. Psikologi Pendidikan. Jakarta: CV Rajawali . 
Syah, Muhibbin, 2010. Psikologi Pendidikan dengan Pendekatan Baru . Bandung: Penerbit Remaja Rosdakarya.

Winkel, W. S. 2004. Psikologi Pengajaran. Yogyakarta: Media Abadi 